\title{
Az európai uniós támogatások hatása a kistérségek helyzetére
}

\author{
Impact of EU subsidies on subregions
}

\author{
FERTŐ IMRE, VARGA ÁGNES
}

FERTŐ Imre: tudományos tanácsadó, MTA Közgazdaság- és Regionális Tudományi Kutatóközpont, Közgazdaság-tudományi Intézet; egyetemi tanár, Budapesti Corvinus Egyetem, Budapest; ferto.imre@krtk.mta.hu, imre.ferto@uni-corvinus.hu

VARGA Ágnes: PhD-hallgató, Eötvös Loránd Tudományegyetem, Budapest;

varga.agi14@gmail.com

\section{KULCSSZAVAK: EU-támogatások, hatásvizsgálat, kistérségek}

ABSZTRAKT: A tanulmány az első kísérlet arra, hogy az európai uniós támogatások hatását ökonometriai módszerekkel vizsgálja a kistérségek helyzetére 2002 és 2008 között. Számításaink szerint a támogatások nagyságrendjének növekedésével azok koncentrációja is jelentősen növekedett. Ugyanakkor a támogatások kistérségek közötti konvergenciája is megfigyelhető volt bizonyos mutatók alapján. Eredményeink arra utalnak, hogy a támogatásoknak általában elég nehéz bármilyen hatását is azonosítani, mivel a mért hatások érzékenyek a választott indikátorra. A kimutatott hatások nagysága nagyon kicsi, ezért azok irányától függetlenül nagy valószínűséggel elenyésző. A támogatások hatásmechanizmusainak feltárásához további kutatások szükségesek.

Imre FERTŐ: research advisor, Institute of Economics, Centre for Economic and Regional Studies, Hungarian Academy of Sciences; professor, Corvinus University of Budapest, Budapest; ferto.imre@krtk.mta.hu,imre.ferto@uni-corvinus.hu

Ágnes VARGA: PhD student, Eötvös Loránd University, Budapest; varga.agi14@gmail.com

KEYWORDS: EU subsidies, impact evaluation, subregion

ABSTRACT: In recent years, evaluating EU co-funded programmes has grown in importance. This paper is a first attempt at analysing the impact of subsidies paid by the European Union towards upgrading rural areas between 2002 and 2008, using a two-stage approach.

In the first stage, we construct a multi-dimensional index measuring the overall level of regional development and quality of life in individual regions of Hungary. In the Regional Development Index (RDI), the development domains are represented by 132 partial socioeconomic, environmental, infrastructural and administrative indicators/variables at LAU1 level. The weights of these economic, social and environmental domains are derived empirically from an econometrically estimated, interregional migration function after selecting the "best" model from various alternative model specifications. The RDI was empirically applied to the regional development in individual rural areas of Hungary in the years 2002-2008. Due to its

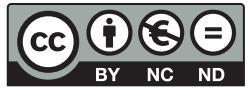


comprehensiveness, RDI is suitable for analysing the overall level of development of rural areas and also for evaluating the impacts of various structural programmes at a regional level.

In the second stage, we apply a propensity-score-matching approach to evaluate the impact of regional subsidies on the RDI. Estimations reveal four main findings. First, calculations suggest that EU subsidies concentrate where there have been previous EU subsidies. Second, some convergence of support can also be observed. Third, we find considerable variation in terms of the level of subsidies during the period analysed. This indicates that there has been a chance for poorly subsidised regions to improve their relative position or weaken their position further. Finally, our results imply that it is very difficult to identify any impacts of subsidies, because estimations are highly sensitive on the chosen parameters. The significance of identified effects is rather low and its direction can be both positive and negative. We conclude that, irrespective of estimated coefficients, the impact of regional subsidies is negligible. As a consequence, further research is needed to explore impacts mechanisms of subsidies.

\section{Bevezetés}

Az elmúlt években az Európai Unió (EU) szakpolitikáinak elemzése egyre nagyobb jelentőségre tett szert. Az Európai Közösség adminisztratív reformja után a periodikus értékeléseket kiterjesztették az összes EU-politikára. Az értékelési gyakorlat az EU-szakpolitikák minden szintjén (EU, nemzeti, regionális) részévé vált a programozásnak.

Az EU definíciója szerint a programértékelés olyan folyamat, amelynek célja a politikai beavatkozások igazolása, értékelése annak alapján, hogy azok hatásaikban, eredményeikben és igényeikben mennyire teljesítették a kitüzött célokat. Az EU-s szabályozás a regionális és vidékfejlesztési programok esetében a következő értékelési formákat különbözteti meg: előzetes (ex ante), közbenső (mid-term), utólagos (ex post) és folyamatértékeléseket. A programok közbenső és utólagos értékelésének fó célja, hogy két szempontból vizsgálja az adott program hatását. Az egyik szempont a program hatásossága abban az értelemben, hogy az mennyire érte el azt a célt, amelyet előzetesen meghatároztak a hozzá tartozó teljesítménykritériummal együtt. A másik szempont a program hatásossága a költség-haszon elemzés szempontjából, azaz hogy a program teljes haszna hogyan aránylik annak költségeihez (European Commission 2006).

A szakpolitikai programok hatáselemzésének irodalma megkülönbözteti a programok közvetlen és közvetett hatásait, valamint a szándékolt és a nem szándékolt (gazdasági, társadalmi, környezeti) hatásokat, amelyek különböző szinteken (egyén, csoport, helyi, regionális, országos, globális) fordulhatnak elö. Az EU értékelési módszertana különbséget tesz a program outputja (fizikai egység), a program eredménye (mikroszinten előforduló hatások), valamint a program hatása között (Bakucs, Fertő 2013). A programok értékelésének nem megfelelő módszertana számos negatív következménnyel járhat (Michalek 2012): 
- A kapott eredmények erősen torzítottak lehetnek (akár negatív, akár pozitív irányban).

- Az ismeretek hiánya a programok valódi hatásairól olyan programok folytatásához vezethet, amelyeket vagy fel kellene függeszteni, vagy át kellene tervezni.

- A programok közvetett hatásai megkérdőjelezhetik a programok számított nettó hatásainak irányát.

- A rosszul tervezett programok a közösségi és magánerőforrások nem hatékony felhasználásához vezethetnek.

- Végezetül az elégtelen tudás és tanulás a programok valódi hatásairól megkérdőjelezheti az EU értékelésének és intézményeinek hitelességét.

A szakpolitikai programok értékelése Magyarországon is megtörtént az EU által meghatározott eljárásrendben. Noha egyre növekvő irodalom foglalkozik az EU szakpolitikai programjainak vizsgálatával, a hazai fejlesztési programok tudományos szempontú hatáselemzése még gyerekcipőben jár (lásd kivételként Molnár, Hamza, Székely, Varga 2011). Ebben a tanulmányban kísérletet teszünk arra, hogy a hatáselemzés legújabb módszertani eredményeit felhasználva hazai fejlesztési programok hatásait elemezzük 2002 és 2008 között.

\section{A programok hatáselemzésének legfontosabb módszertani problémái}

A szakpolitikai programok hatáselemzésének módszertana az elmúlt két évtizedben sokat fejlődött. Kitűnő, nem technikai áttekintést adnak a nemzetközi irodalomról Gertler, Martinez, Premand, Rawlings, Vermeersch (2011), Kandhker, Koolwal, Samad (2010), illetve magyarul Kézdi (2010).

A fejlesztési programok hatásaival foglalkozó szakirodalom alapvetően utólagos jellegü. A kutatóknak a vizsgálat során a következő módszertani nehézségekkel kell szembenézniük (Michalek 2012):

- Empirikus tényeket kell találni a valódi ok-hatás kapcsolatról a kiválasztott programindikátor és a fejlesztési program között.

- Minden egyes (gazdasági, társadalmi, környezeti) hatásindikátorra el kell különíteni a fejlesztési program hatását más exogén tényezőktől.

- A fejlesztési programok hatását mérni és aggregálni kell.

- Az EU programértékelési eljárásrendjének megfelelően költség-haszon elemzést kell végezni az adott programról.

A fenti nehézségek számos tényezőre vezethetők vissza, amelyek közül kettőnek kitüntetett jelentősége van.

Az egyik nehézség, hogy a szakpolitikai programok hatáselemzésének kulcskérdése a megfelelő tényellentétes helyzet létrehozása. Az alapvető probléma az, hogy ideális tényellentétes állapot nem hozható létre, amelyben össze- 
hasonlithatnánk egy programban való részvétel hatását, mivel a megfigyelés egysége (pl. az egyén) vagy részt vett egy programban, vagy nem. Másképpen fogalmazva nem tudunk létrehozni olyan helyzetet, hogy ugyanazt az egyént egyidejűleg két különböző helyzetben (pl. kapott támogatást vagy nem) megfigyelhessük. A tényellentétes eredményeknek kitüntetett szerepe van a hatáselemzésben, ugyanakkor nem tudjuk közvetlenül mérni őket. A programok hatáselemzését a tényellentétes eredmények szempontjából a következő csoportokba sorolhatjuk (Baker 2000):

- Módszerek, amelyek nem használnak tényellentétes helyzeteket. Ilyenek például a kvalitatív tanulmányok, amelyek megpróbálják az adott program hatását felmérni fókuszcsoportos, interjús vagy más kvalitatív felméréssel, amelyet a program előtt, alatt és után végeznek el. Ez tipikusan előtte/utána megközelítés, amelyben kulcsváltozók teljesítményét hasonlítják össze a program előtt, alatt, illetve után.

- A második csoportba azok a módszerek tartoznak, ahol tényellentétes állapotokat hoznak létre különböző feltevések alkalmazásával. Ebbe a csoportba sorolhatók például a kiszámítható általános egyensúlyi modelleket vagy regionális input-output modelleket alkalmazó vizsgálatok.

- A harmadik csoportba az úgynevezett naiv megközelítés tartozik, amelyben néhány megfigyelt teljesítményindikátor változását figyelik meg egy adott program vizsgálatára létrehozott mintában, néhány önkényesen kiválasztott csoportban.

- Végezetül vannak olyan statisztikai, ökonometriai módszerek, amelyek kontrollálják a kezdeti állapotban és a politikákban megfigyelhető különbségeket.

Ha arra vagyunk kíváncsiak, hogy egy-egy térségre milyen hatást gyakoroltak az ott kifizetett támogatások (a módszertani problémákról bővebben lásd Bakucs, Fertő 2013), akkor az elemzésnél a másik, sajátos problémával kell szembenéznünk, a komplexitással. A komplexitás két szempontból is jelentős. Egyrészt a fejlesztési programok külön-külön (de némelyikük önmagában is, lásd vidékfejlesztési program) számos célt akarnak elérni és ezért több eszközt alkalmaznak egyidejűleg, másrészt ez nyilván azt is jelenti, hogy az értékelésnek többdimenziósnak kell lennie. A programok teljes hatásának értékelésénél egyidejüleg kell figyelembe venni azok gazdasági, társadalmi és környezeti hatásait. Ez a feladat olyan módszertani megoldásokat igényel, amelyek kombinálásával konzisztens összhatást mérhetünk minden intézkedés esetében. Az EU által létrehozott értékelési eljárásrend nem rendelkezik ilyen tulajdonságokkal, a vizsgálatok többsége leginkább a naiv módszertant követi. Összefoglalva, a fejlesztési programok (ezeket a továbbiakban térségfejlesztési programoknak hívjuk) együttes hatáselemzése regionális és makroszinten átfogó és szigorú módszertan alkalmazását követeli meg. 


\section{A térségfejlesztési programok lehetséges hatásindikátora, a térségfejlettségi index}

A térségfejlesztési programok hatásának számbavétele egyszerre igényli a térségek gazdasági, társadalmi és környezeti állapotának vizsgálatát. A térségfejlesztési programok standard indikátora a regionális egy főre jutó GDP, amelyet NUTS2 vagy NUTS3 szinten kiszámolnak. Ez a mérőszám például a strukturális alapokhoz való hozzáférés alapja. A GDP nem feltétlenül jó mérőszáma az általános társadalmi-gazdasági állapotnak. Az egy főre jutó regionális GDP mellett számos részindikátort alkalmaznak, amelyek a térségfejlesztés valamilyen aspektusát (gazdasági, társadalmi, környezeti) próbálják mérni. Ezek a mérőszámok külön-külön nyilvánvalóan nem alkalmasak a térségek állapotának, az állapotváltozásnak az értékelésére. A kérdés az, hogy vajon a rendelkezésre álló adatokból lehet-e egyetlen olyan mutatószámot létrehozni, amely több dimenzióban, alacsonyabb területi szinten képes mérni a térségek állapotát. Michalek és Zarnekow (2012) komplex vidékfejlesztési indexe megfelel ezeknek a követelményeknek. A vidékfejlesztési index (RDI) az alábbi módon írható le.

$$
\mathrm{RDI}_{\mathrm{i}}=\mathrm{h}\left(\beta_{\mathrm{k}}, \mathrm{Z}_{\mathrm{k}}^{\mathrm{i}}\right)=\Sigma_{\mathrm{k}} \beta_{\mathrm{k}} \times \mathrm{Z}_{\mathrm{k}}^{\mathrm{i}}
$$

ahol RDI ${ }_{\mathrm{i}}$ a vidékfejlesztési index i régióban, $\mathrm{z}_{\mathrm{k}}{ }^{\mathrm{i}} \mathrm{i}$ régió $\mathrm{k}$ mérhető jellemzője, $\beta_{\mathrm{k}}$ a súlyok minden egyes $\mathrm{k}$ jellemzőre, amelyeket a migrációs függvényből (2. egyenlet), becslünk és amelyek specifikusak mind i régióra, mind t időpontra.

Az RDI komplex indikátor, $Z_{i}$ regionális jellemzőkön alapul, amelyeket a migrációs függvény együtthatójával $\left(\beta_{k}\right)$ súlyozunk. A modellel becsült $\beta_{k}$ súly minden egyes $Z_{\mathrm{i}}$ regionális jellemző relatív súlyát vagy „társadalmi értékét” mutatja.

$A Z_{i}$ regionális jellemzők becslése faktorelemzéssel történik, amelybe minden releváns, regionálisan rendelkezésre álló változót bevonnak, amelyek leírják az adott régió társadalmi, gazdasági és környezeti aspektusát. A migrációs függvény alapváltozata a következő:

$$
\mathrm{mp}_{\mathrm{it}}=\alpha_{0}+\beta_{\mathrm{k}} \mathrm{F}_{\mathrm{ikt}}+\mathrm{v}_{\mathrm{i}}+\varepsilon_{\mathrm{it}},(2)
$$

ahol $\mathrm{mp}_{\mathrm{it}}$ i régióba való nettó bevándorlás t időszakban, $\mathrm{F}_{\mathrm{ikt}}$ a faktorok $\mathrm{k}$ értéke i régióban $\mathrm{t}$ időszakban, $\mathrm{v}_{\mathrm{i}}$ a régióspecifikus reziduum, $\varepsilon_{\mathrm{it}}$ a reziduum a szokott tulajdonságokkal.

Mivel Michalek és Zarnekow (2012) részletesebb adatokkal rendelkeztek Lengyelországra és Szlovákiára, ezért a migrációs függvénybe bevonták a régiók közötti távolság négyzetét. Esetünkben nem állnak rendelkezésünkre a régiók közötti migrációs adatok, azaz nem tudjuk, hogy honnan hová költöznek a magyar állampolgárok. Csak arra van információnk, hogy hányan költöztek be, illetve hányan költöztek el egy adott régióból, ezért a távolságváltozót nem tudtuk beépíteni a migrációs egyenletbe. 
Tanulmányunkban Michalek és Zarnekow indexét a hazai viszonyokra adaptáltuk és térségfejlettségi indexként hívjuk. Ennek oka, hogy számításainkba Budapestet és a vidéki nagyvárosokat is bevontuk. (A térségfejlettségi index kiszámításának módjáról, annak eredményeiről bővebben lásd Fertő, Varga 2014.)

\section{Adatok}

A térségfejlettségi index kiszámításához a KSH Településstatisztikai Adatbázisrendszerét (T-STAR) használjuk, amelyet az MTA KRTK Adatbankja bocsátott a rendelkezésünkre (az adatbázisról lásd Németh é. n.). A T-STAR adatbázis településszintủ adatait a 174 kistérség szintjére összegeztük. A térségfejlettségi indexek kiszámításához 132 változót használtunk az alábbi, számunkra releváns témakörökből: demográfia (15 változó), egészségügy (9), gazdálkodó szervezetek (2), kereskedelem és vendéglátás (24), közlekedés és hírközlés (7), kommunális infrastruktúra (14), környezetszennyezés (4), kultúra és közművelődés (2), lakásállomány (5), munkanélküliség (4), oktatás (16), önkormányzati segélyezés (5), szociális ellátás (12), turizmus és vendéglátás (9), személyi jövedelemadó (3), falvak száma a kistérségben (1).

Figyelembe véve az adatok hozzáférhetőségét vizsgálatunk a 2002 és 2008 közötti időszakot fogja át, elemzésünk így tartalmazza az EU-csatlakozás előtti és utáni időszakot is. Erre a periódusra álltak rendelkezésre a legteljesebben a relevánsnak tűnő változók. Az egyes változók aránya a különböző dimenziókban nem kiegyensúlyozott. Itt azzal a dilemmával néztünk szembe, hogy vagy minél több változót vonunk be a vizsgálatba a teljesség igényével, vagy szelektálunk az egyes változók között, hogy az egyes témák arányosan szerepeljenek a mintában. Annak érdekében, hogy az elemzés során minél több információt használjunk fel, az előbbi megoldás mellett döntöttünk. Célunk az volt, hogy a lehetséges leghosszabb periódust vizsgálhassuk.

A fejlesztési támogatások adatainak forrásául a VÁTI által üzemeltetett TeIR (Országos Területfejlesztési és Területrendezési Információs Rendszer) adatbázisa szolgált. 2002 és 2008 közötti elemzéseinkhez a települési szinten szereplő támogatások összegét (millió forint) és a településenkénti projektek számát vettük alapul, melyeket kistérségi szintre aggregáltunk.

\section{A fejlesztési támogatások}

A vizsgálatba bevont fejlesztési támogatások leíró statisztikáit az 1. táblázat mutatja a 2002 és 2008 közötti időszakra. Láthatjuk, hogy volt olyan kistérség, amely egyáltalán nem kapott támogatást, míg a legmagasabb támogatási összeg 
1. táblázat: A támogatások mutatóinak leíró statisztikája Descriptive statistics of EU subsidies

\begin{tabular}{lrrrrr}
\hline & $N$ & Átlag & Szórás & Minimum & Maximum \\
\hline Támogatás (millió Ft) & 1218 & 2253 & 18021 & 0 & 505647 \\
Projekt (db) & 1218 & 88 & 171 & 2 & 3686 \\
Támogatás / projekt (millió Ft) & 1218 & 23 & 40 & 0 & 541 \\
Támogatás / fó (ezer Ft) & 1218 & 29 & 39 & 0 & 661 \\
Támogatás / km² (millió Ft) & 1218 & 4 & 34 & 0 & 963 \\
\hline
\end{tabular}

505 milliárd forint volt. A támogatások átlagos összege kistérségenként 2,2 milliárd forint volt. A támogatások összege rendkívül nagy szórást mutat kistérségenként, és ha az elfogadott projektek számát vesszük szemügyre, hasonló kép bontakozik ki. A projektek száma minimálisan kettő volt, de volt olyan térség, ahol közel 3700 projektet fogadtak el, a projektek átlagos száma kistérségenként 88 volt. A támogatások egyéb származtatott mutatóit is kiszámoltuk. Az egy projektre jutó támogatás átlaga 22,5 millió forint, minimuma nem érte el a milliós nagyságrendet, maximuma pedig 540 millió forint volt. Az egy főre jutó támogatás átlaga 29 ezer forint, míg az egy négyzetkilométerre jutó támogatásé 4,3 millió forint volt. Az egy före jutó támogatás eloszlása sokkal egyenletesebb volt, mint a területre jutó támogatás, amelyet a relatív szórás lényegesen alacsonyabb értéke jelez. A két származtatott mutató maximuma is nagyságrendi eltérést mutat: az egy före jutó támogatás maximuma 661 ezer, míg az egy négyzetkilométerre jutóé 963 millió forint. Összefoglalva, a támogatások leíró statisztikái meglehetősen egyenlőtlen eloszlásra utalnak.

A támogatások átlagának változását évenként a 2. táblázat mutatja. A számítások szerint az EU-csatlakozás előtt, illetve az EU-csatlakozás évében a támogatás összegének átlaga egymilliárd forint körül mozgott. Ezt követően az összegek jelentős hullámzással, de többszörösükre emelkedtek. A projektek száma kistérségenként jelentősen csökkent, különösen 2004 után. Ezzel együtt járt az egy projektre jutó támogatási összegek dinamikus emelkedése. Az egy

2. táblázat: A támogatások és a projektszámok átlaga kistérségenként 2002-2008 Subsidies and number of projects by subregions, 2002-2008

\begin{tabular}{lccccc}
\hline Év & $\begin{array}{c}\text { Támogatás } \\
(\text { millió } \mathrm{Ft})\end{array}$ & Projekt $(\mathrm{db})$ & $\begin{array}{c}\text { Támogatás/ } \\
\text { projekt }(\text { millió } \mathrm{Ft} \text { ) }\end{array}$ & $\begin{array}{c}\text { Támogatás } / \mathrm{fó}^{\prime \prime} \\
(\mathrm{ezer} \mathrm{Ft})\end{array}$ & $\begin{array}{c}\text { Támogatás } / \mathrm{km}^{2} \\
\text { (millió } \mathrm{Ft} \text { ) }\end{array}$ \\
\hline 2002 & 1028 & 135 & 8 & 23 & 2,0 \\
2003 & 997 & 110 & 9 & 22 & 1,8 \\
2004 & 1160 & 134 & 9 & 19 & 2,2 \\
2005 & 2852 & 91 & 31 & 51 & 5,4 \\
2006 & 1737 & 58 & 30 & 30 & 3,4 \\
2007 & 2328 & 38 & 61 & 7 & 4,4 \\
2008 & 5668 & 46 & 124 & 49 & 10,6 \\
\hline Összesen & 15769 & 613 & 271 & 201 & 29,8 \\
\hline
\end{tabular}


projektre jutó támogatás 8 millió forintról 124 millióra növekedett. Az egy före jutó támogatásokban az egy egységre jutó támogatás több mint duplájára nőtt, míg az egy négyzetkilométerre jutó támogatások esetében a növekedés meghaladta az ötszörös mértéket.

A támogatások Lorenz-görbéi megerősítik a területi koncentráció növekedésére vonatkozó sejtéseinket (1. ábra). A koncentráció mértéke a támogatások abszolút összegében, illetve az egy négyzetkilométerre jutó támogatásoknál volt a legnagyobb, míg az egy fóre jutó támogatások esetében a legkisebb a vizsgált időszak egészében. Emellett a koncentráció a három mutató esetében jelentősen nőtt 2002 és 2008 között (2. ábra).

1. ábra: A támogatások és a projektek kistérségi megoszlásának Lorenz-görbéje, 2002-2008 Lorenz curves of the subregional distribution of subsidies and project numbers

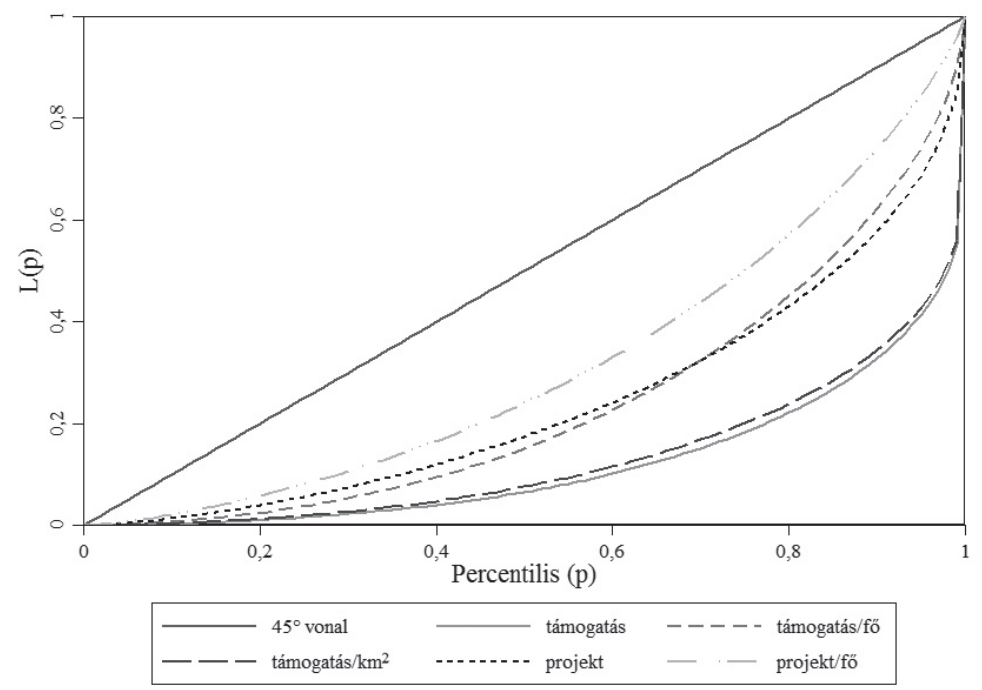

2. ábra: A támogatások kistérségi megoszlásának Lorenz-görbéje 2002-ben és 2008-ban Lorenz curves of the subregional distribution of subsidies in 2002 and 2008
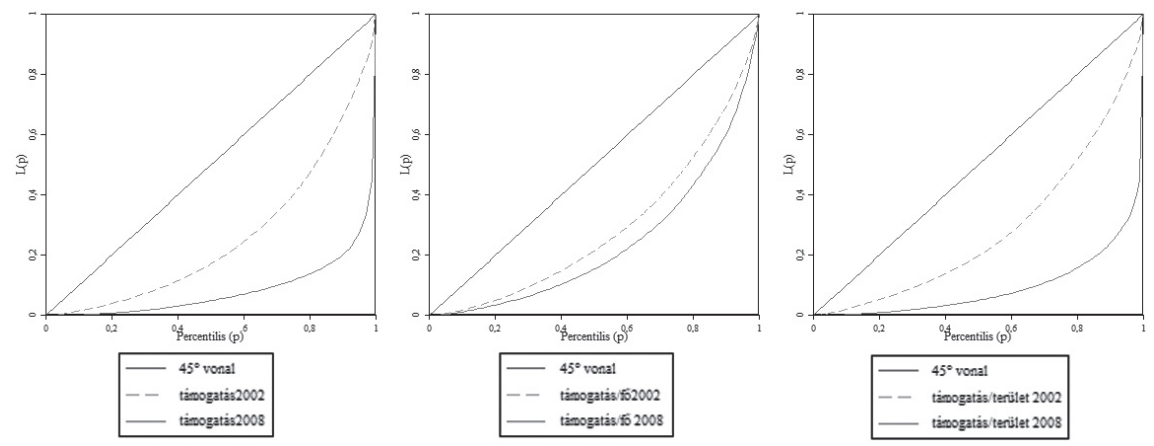


\section{A fejlesztési támogatások stabilitása}

A támogatási értékek stabilitásának mérésére számos eszköz áll rendelkezésünkre. Érdemes azonban megkülönböztetni legalább két típusú stabilitást: a támogatások eloszlásának stabilitását két időszak között, valamint a támogatások értékének stabilitását az adott kistérségben két időszak között. A támogatási eloszlás stabilitásának vizsgálata azt az általánosabb kérdést is felveti, hogy az egyes térségek támogatottsága konvergál vagy divergál-e.

A gazdasági adatok konvergenciavizsgálatának módszertana sokat változott az elmúlt évtizedekben az egyszerủ Galtoni-regressziótól a panelegységgyöktesztekig. A közgazdasági vizsgálatokban a konvergencia vizsgálata a gazdasági növekedés elemzésétől indult. A gazdasági fejlettség konvergenciájára kidolgozott empirikus módszertant más kérdések vizsgálatára is jól lehet alkalmazni, mint például az infláció (Lopez, Papell 2012) vagy a kereskedelem specializációjának elemzésére (Fertő 2006). Bernard és Durlauf (1996) szerint a hosszú távú outputváltozások két vagy több ország között akkor konvergálnak, ha az egy főre jutó kibocsátáskülönbségek hosszú távú előrejelzése nullához tart, amikor az előrejelzés horizontja a végtelenhez tart. Kétváltozós összefüggésben ez azt jelenti, hogy az idősorok akkor konvergálnak, ha az országok között az egy főre jutó GDP-különbségek stacionáriusak. Többváltozós vagy panelkontextusban az értelmezés hasonló: az országok egy csoportja akkor konvergál, ha az országok közötti kibocsátáskülönbségek stacionáriusak. Nyilvánvalóan a GDP konvergenciájának vizsgálatát analóg módon használhatjuk a fejlesztési támogatások elemzésére.

A paneladatok ökonometriája számos panelegységgyök-eljárást fejlesztett ki az elmúlt évtizedben (Baltagi 2008). A szakirodalom általában első- és másodgenerációs egységgyököket különböztet meg aszerint, hogy a paneladatokban közös vagy egyéni egységgyökfolyamatot feltételezünk. Mivel a különböző teszteknek előnyei és hátrányai is vannak, ezért eredményeink robusztusságának ellenőrzésére több panelegységgyöktesztet is alkalmazunk. A panelegységgyökök tesztelését két lépcsőben végezzük el. Először csak individuális hatást, másodszor pedig individuális és trendhatást is feltételezünk.

Trendhatás nélkül a panelegységgyöktesztek egyértelmű eredményt adnak (3. táblázat), az összes teszt elutasítja az egységgyök létét az vidékfejlesztési támogatások paneladataiban.

Trendhatást feltételezve hasonló eredményekre juthatunk (4. táblázat). Az öt teszt közül csak az Im, Pesaran és Shin-teszt nem utasítja el az egységgyökök létezését, ezért a vizsgált fejlesztési támogatások adatai valószínűleg stacionáriusak, azaz a vizsgált fejlesztési támogatások Magyarországon a kistérségek között valószínủleg konvergáltak 2002 és 2008 között. Eredményeink robusztusak az alternatív támogatási indikátorokra, mint az egy fóre jutó és az egy négyzetkilométerre jutó támogatások. (Az eredmények érdeklődés esetén a szerzőknél rendelkezésre állnak.) 
3. táblázat: A fejlesztési támogatások panelegységgyöktesztjei (individuális hatás) Panel unit root tests of subsidies (individual effect)

\begin{tabular}{lcc}
\hline \multicolumn{1}{c}{ Módszer } & Statisztika & Valószínüség** $^{*}$ \\
\hline Nullhipotézis: egységgyök (közös egységgyökfolyamatot feltételezve) & & \\
\hline Levin, Lin és Chu t* & $-30,128$ & 0,000 \\
\hline Nullhipotézis: egységgyök (egyéni egységgyökfolyamatot feltételezve) & & \\
\hline Im, Pesaran és Shin W-statisztika & $-9,071$ & 0,000 \\
ADF - Fisher Chi-négyzet & 678,030 & 0,000 \\
PP - Fisher Chi-négyzet & 885,139 & 0,000 \\
\hline
\end{tabular}

4. táblázat: A fejlesztési támogatások panelegységgyöktesztjei (trend és individuális hatás) Panel unit root tests of subsidies (trend and individual effects)

\begin{tabular}{lrc}
\hline \multicolumn{1}{c}{ Módszer } & Statisztika & Valószínüség* $^{* *}$ \\
\hline Nullhipotézis: egységgyök (közös egységgyökfolyamatot feltételezve) & & \\
\hline Levin, Lin és Chu t* & $-30,969$ & 0,000 \\
Breitung t-statisztika & $-1,369$ & 0,086 \\
\hline Nullhipotézis: egységgyök (egyéni egységgyökfolyamatot feltételezve) & & \\
\hline Im, Pesaran és Shin W-statisztika & $-0,740$ & 0,230 \\
ADF - Fisher Chi-négyzet & 410,699 & 0,016 \\
PP - Fisher Chi-négyzet & 709,659 & 0,000 \\
\hline
\end{tabular}

\section{A fejlesztési támogatások dinamikája}

A konvergenciavizsgálat nem ad információt az eloszláson belüli lehetséges változásokról. Ezért a kistérségeket négy kvartilisbe osztottuk a támogatások értékei alapján. Ez alapján becsültük a Markov-féle valószínűségátmeneti mátrixot. Az 5. táblázatból láthatjuk, hogy a kistérségek meglehetősen nagy valószínűséggel mozognak egyik kvartilisből a másikba. Az adott kvartilisben maradás esélye 24 és 40 százalék közötti. Érdemes kiemelni, hogy a támogatások legmagasabb csoportjában való maradásnak közel 40 százalékos az esélye. A legjobb pozíció rontásának esélye csökken az 1. kvartilis irányába, ezzel szemben az alsó két kvartilisből a negyedik kvartilisbe való kerülés valószínűsége 20 százalék alatt van. A második és a harmadik kvartilisben a pozícióromlás esélye

5. táblázat: A kistérségek Markov-mátrixa a fejlesztési támogatások kvartilisértékei alapján, 2002-2008

Markov matrix of subsidies of subregions, by quartiles, 2002-2008

\begin{tabular}{lcccc}
\hline & 1. kvartilis & 2. kvartilis & 3. kvartilis & 4. kvartilis \\
\hline 1. kvartilis & 0,2820 & 0,2459 & 0,2820 & 0,1902 \\
2. kvartilis & 0,3410 & 0,2492 & 0,2328 & 0,1770 \\
3. kvartilis & 0,2376 & 0,2871 & 0,2409 & 0,2343 \\
4. kvartilis & 0,1447 & 0,2204 & 0,2401 & 0,3947 \\
\hline
\end{tabular}


relatíve magas: 34, illetve 52 százalék. Számításaink felhívják a figyelmet arra, hogy a támogatásokban kimutatható általános konvergencia mellett jelentős mobilitást tapasztalhatunk az egyes kistérségek fejlesztési támogatásokhoz való hozzájutásában. A mobilitás mindkét irányban működik. Egy 2002-ben sok támogatást kapott kistérség visszacsúszhat a relatíve kevesebb támogatást kapott kistérségek közé, és ennek az ellenkezője is megtörténhet. A mobilitás azért különösen fontos, mivel a vizsgált időszak során a fejlesztési támogatások összege jelentősen megnövekedett.

\section{A fejlesztési támogatások hatása}

A fejlesztési programok hatását végezetül a becsült részvételi valószínűségen (propensity score matching, PSM) alapuló párosítás módszerével vizsgáljuk (a becslésekhez a Stata psmatch2 programját alkalmaztuk). A módszerről részletesebben lásd Guo és Fraser (2010) könyvét. A becsült részvételi valószínűség a fejlesztési programban való részvétel valószínűsége a kontrollváltozók függvényében, valamennyi megfigyelési egységre (esetünkben kistérségre) megbecsülve. A programok hatásának megfelelő becslése megkívánja a megfelelő párosítási algoritmus alkalmazását. A legtöbbet alkalmazott párosítási algoritmusok a következők: a legközelebbi szomszéd, a rádiuszpárosítás, a stratifikációs párosítás és a kernelpárosítás (Abadie, Drukker, Herr, Imbens 2004; Leuven, Sianesi 2009). Míg aszimptotikusan minden párosítási eljárásnak azonos eredményre kell vezetnie, a párosítási eljárás kiválasztása különbséget okozhat kis mintákban. A megfelelő párosítási eljárás kiválasztásában a következő kritériumokat alkalmaztuk: a) standardizált torzítás, b) t-teszt és c) közös szignifikancia és pszeudo $\mathrm{R}^{2}$.

A korábbiakhoz hasonlóan a számításokat elvégeztük mindhárom támogatási mutatóra: a támogatások összegére, az egy főre jutó támogatásokra és az egy négyzetkilométerre jutó támogatásokra. Első lépcsőben következő logit modellt becsültük minden egyes mutatóra:

$$
\text { Támogatás } s_{\mathrm{it}}=\alpha_{0}+\alpha_{1} \text { TFI2002 } 2_{\mathrm{it}}+\alpha_{2} \mathrm{MN} 002_{\mathrm{it}}+\alpha_{3} \mathrm{UNEMP} 2002_{\mathrm{it}}+\mathrm{V}_{\mathrm{i}}+\varepsilon_{\mathrm{it}}(3),
$$

ahol a TFI2002 ${ }_{\text {it }}$ és MN2002 ${ }_{\text {it }}$ az adott kistérség kiinduló állapotát kontrollálja a kistérség fejlettségének és a munkanélküliség abszolút számának 2002. évi helyzetével. A modellt kiegészítettük az UNEMP2002 $2_{\text {it }}$ változóval, amely a munkanélküliség arányát mutatja az adott kistérségben. Majd a logit modellek eredményeit használtuk az egyes kistérségek támogatási programokban való becsült részvételi valószínűségének a kiszámítására. A párosítási eljárások kiegyensúlyozottsági tesztjeit mutatják a 6-8. táblázatok. A tesztek mindhárom támogatási mutató esetében megerősítik a párosítási eljárások helyességét. Ahol a 
6. táblázat: A támogatási összeg kiegyensúlyozottsági tesztje (közös értelmezési tartomány:

kistérség, biweight kernel) a támogatott és nem támogatott kistérségekben

Similarity tests of subsidies (common support: subregion, biweight kernel) in subsidised and not subsidised subregions

\begin{tabular}{llrrrrrr}
\hline \multirow{2}{*}{ Változó } & \multicolumn{1}{c}{ Minta } & \multicolumn{2}{c}{ Átlag } & \multicolumn{2}{c}{$\%$-os csökkenés } & \multicolumn{2}{c}{ t-teszt } \\
\cline { 3 - 8 } & & \multicolumn{1}{c}{ Kezelt } & Kontroll & \%-os torzítás & Torzitás & $t$ & $p>t$ \\
\hline \multirow{2}{*}{ TFI2002 } & Párosítatlan & 0,0001 & 0,0002 & $-4,9$ & & $-0,83$ & 0,406 \\
& Párosított & 0,0001 & 0,0001 & 0,2 & 9,0 & 0,04 & 0,967 \\
\multirow{2}{*}{ MN2002 } & Párosítatlan & 363,8300 & 154,8000 & 22,3 & & 3,49 & 0,000 \\
& Párosított & 175,9000 & 147,0300 & 3,1 & 86,2 & 1,01 & 0,311 \\
\multirow{2}{*}{ UNEMP2002 } & Párosítatlan & 0,0066 & 0,0057 & 5,0 & & 0,83 & 0,407 \\
& Párosított & 0,0045 & 0,0035 & 5,4 & $-9,0$ & 1,32 & 0,186 \\
\hline
\end{tabular}

7. táblázat: Az egy före jutó támogatás kiegyensúlyozottsági tesztje

(közös értelmezési tartomány: kistérség, biweight kernel)

a támogatott és nem támogatott kistérségekben

Similarity tests of subsidies per capita (common support: subregion, biweight kernel) in subsidised and not subsidised subregions

\begin{tabular}{llrrcccc}
\hline \multirow{2}{*}{ Változó } & \multirow{2}{*}{ Minta } & \multicolumn{2}{c}{ Átlag } & \multicolumn{2}{c}{ \%-os csökkenés } & \multicolumn{2}{c}{ t-teszt } \\
\cline { 3 - 8 } & & Kezelt & Kontroll & \%-os torzítás & Torzítás & $t$ & $p>t$ \\
\hline \multirow{2}{*}{ TFI2002 } & Párosítatlan & 0,0002 & 0,0001 & 6,7 & & 1,90 & 0,276 \\
& Párosított & 0,0001 & 0,0001 & 4,3 & 35,9 & 1,10 & 0,311 \\
\multirow{2}{*}{ MN2002 } & Párosítatlan & 332,5100 & 201,29 & 8,1 & & 2,17 & 0,030 \\
& Párosított & 175,8400 & 153,26 & 2,4 & 82,8 & 0,79 & 0,430 \\
\multirow{2}{*}{ UNEMP2002 } & Párosítatlan & 0,0064 & 0,0061 & 1,7 & & 0,29 & 0,770 \\
& Párosított & 0,0048 & 0,0046 & 1,0 & 45,3 & 0,22 & 0,829 \\
\hline
\end{tabular}

8. táblázat: Az egy négyzetkilométerre jutó támogatás kiegyensúlyozottsági tesztje (közös értelmezési tartomány: kistérség, biweight kernel)

a támogatott és nem támogatott kistérségekben

Similarity tests of subsidies per square kilometre (common support: subregion, biweight kernel) in subsidised and not subsidised subregions

\begin{tabular}{llrccccc}
\hline \multirow{2}{*}{ Változó } & \multicolumn{1}{c}{ Minta } & \multicolumn{2}{c}{ Átlag } & \multicolumn{2}{c}{ \%-os csökkenés } & \multicolumn{2}{c}{ t-teszt } \\
\cline { 3 - 8 } & & Kezelt & Kontroll & \%-os torzitás & Torzitás & $t$ & $p>t$ \\
\hline TFI2002 & Párosítatlan & 0,0002 & 0,0001 & 6,7 & & 1,90 & 0,276 \\
& Párosított & 0,0001 & 0,0001 & 4,3 & 35,9 & 1,10 & 0,311 \\
\multirow{2}{*}{ MN2002 } & Párosítatlan & 332,5100 & 201,29 & 8,1 & & 2,17 & 0,030 \\
& Párosított & 175,8400 & 153,26 & 2,4 & 82,8 & 0,79 & 0,430 \\
UNEMP2002 & Párosítatlan & 0,0064 & 0,0061 & 1,7 & & 0,29 & 0,770 \\
& Párosított & 0,0048 & 0,0046 & 1,0 & 45,3 & 0,22 & 0,829 \\
\hline
\end{tabular}

párosítás előtt az egyes változók átlagai szignifikánsan különböztek, ott a párosítás után már nem találtunk szignifikáns különbségeket. A pszeudo $\mathrm{R}^{2}$-tesztek szintén megerősítik a párosítási eljárások megfelelőségét (9. táblázat). 
9. táblázat: A párosítási eljárások pszeudo $\mathrm{R}^{2}$-tesztjei Pseudo $R^{2}$ tests of pair matching

\begin{tabular}{|c|c|c|c|c|c|}
\hline Minta & Pszeudo $R^{2}$ & LR chi ${ }^{2}$ & $p>c h i^{2}$ & A torzítás átlaga & A torzítás mediánja \\
\hline \multicolumn{6}{|l|}{ Támogatás } \\
\hline Nyers & 0,026 & 42,15 & 0,000 & 10,7 & 5,0 \\
\hline Párosított & 0,001 & 2,35 & 0,504 & 2,9 & 3,1 \\
\hline \multicolumn{6}{|c|}{ Egy főre jutó támogatás } \\
\hline Nyers & 0,014 & 22,56 & 0,000 & 4,1 & 4,2 \\
\hline Párosított & 0,000 & 0,91 & 0,822 & 1,8 & 1,2 \\
\hline \multicolumn{6}{|c|}{ Egy hektárra jutó támogatás } \\
\hline Nyers & 0,008 & 12,59 & 0,006 & 7,4 & 6,7 \\
\hline Párosított & 0,002 & 3,27 & 0,352 & 2,6 & 2,4 \\
\hline
\end{tabular}

A becsült részvételi valószínűségen alapuló becslések érvényességének másik sarokpontja a közös értelmezési tartomány vagy átfedés feltételének ellenőrzése (Caliendo, Kopeinig 2005). A teszt lényege a becsült valószínűségi pontok eloszlásának összehasonlítása a közös támogatás mintájában mind a kezelt (esetünkben támogatott), mind a kontrollcsoportban, amely történhet például grafikus (kernel sűrűségfüggvények vagy hisztogramok) vagy paraméteres és nem paraméteres statisztikai tesztek segítségével. A Smirnov-Kolmogorovtesztek eredménye azt sugallja, hogy a párosítás után nem utasíthatjuk el a két csoport eloszlásának egyenlőségét 1\%-os szignifikanciaszint mellett.

A fejlesztési programok átlagos hatását a programokban részt vevő kistérségek fejlettségi szintjére (ATT: average effect of treatment on the treated) kétféle módon is megbecsültük. Egyrészt nem paraméteres kernelalapú párosítás segítségével, amelyet bootstrap technikával becsültünk. Ugyanakkor a bootstrap módszerek nem mindig adnak a párosítás varianciabecslésére megfelelő eredményt (Abadie, Drukker, Herr, Imbens 2004). Ezért olyan legközelebbi szomszéd párosítási eljárást is alkalmaztunk (SATT), amely lehetővé teszi a torzítás korrigálását (bias adjustment), illetve a heteroszkedasztikus robusztus variancia becslését (a számításokat a Stata nnmatch programjával végeztük el).

A kétféle eljárással kapott becsléseinket a 10. táblázat mutatja. A számítások közös eredménye, hogy a becsült hatások igen alacsonyak, közel vannak a nullához. A támogatások összegének és az egy négyzetkilométerre jutó támogatásoknak pozitív hatása van a kistérségek fejlettségére. Előbbi mutató esetében azonban a hatás csak 10\%-on szignifikáns és csak a bootstrap technikával becsült modell esetében. Az egy négyzetkilométerre jutó támogatások mindkét megközelítés esetében 1\%-os szinten szignifikánsak. Ezzel szemben az egy fơre jutó támogatások negatívan befolyásolják a térség fejlettségét, a becslési eljárástól függetlenül.

A becsült részvételi valószínűségen alapuló módszereknek ugyanúgy szembe kell nézniük a szelekciós torzítás problémájával, mint más kísérleti vagy kvázi kísérleti modelleknek. Rosenbaum (2002) azt ajánlja a kutatóknak, hogy végezzenek érzékenységi elemzést. A módszer lényege, hogy meghatározzuk, 
10. táblázat: A fejlesztési támogatások (ATT) becsült hatása Average effect of treatment of subsidies

\begin{tabular}{lcccc}
\hline & Együttható & Szórás & $z$ & $P>z$ \\
\hline ATT & & & & \\
\hline Támogatás* & 0,0005 & 0,0003 & 1,67 & 0,095 \\
Egy före jutó támogatás* & $-0,0015$ & 0,0003 & $-4,63$ & 0,000 \\
Egy km²-re jutó támogatás* & 0,0001 & 0,0003 & 3,69 & 0,000 \\
\hline SATT & & & 1,49 & 0,137 \\
\hline Támogatás & 0,0004 & 0,0003 & $-4,07$ & 0,000 \\
Egy före jutó támogatás & $-0,0013$ & 0,0003 & 3,52 & 0,000 \\
Egy km ${ }^{2-}$-re jutó támogatás & 0,0001 & 0,0003 & \\
\hline
\end{tabular}

* bootstrap z statisztika 200 ismétléssel.

Megjegyzés: *bootstrap z statisztika 200 ismétléssel.

mekkora szelekciós vagy rejtett torzítás szükséges ahhoz, hogy elutasítsuk a nincs hatás nullhipotézisét. Más szavakkal arra keressük a választ, hogy milyen erősen kell a nem megfigyelhető változóknak befolyásolniuk a szelekciós folyamatot, hogy megkérdőjelezhetővé váljanak a becsült feltételes valószínűségen alapuló elemzések következtetései.

Vizsgálatunkban ezért úgynevezett Rosenbaum-sávokat számoltunk a fejlesztési programok átlagos kezelési hatására a programokban résztvevő kistérségekre a nem megfigyelhető heterogenitás tesztelésére a kezelt és a kontrollcsoportok között (a számításokat a STATA rhbounds programjával végeztük el). A gamma értékének már 10\%-os növekedése az eredmények szignifikanciájának elvesztését jelenti a támogatások és az egy négyzetkilométerre jutó támogatások mutatói esetében. Ezzel szemben az egy före jutó támogatásokra vonatkozó érzékenységi vizsgálatok sokkal jobb eredményt hoztak: a gamma akár 50\%-os emelése mellett is szignifikánsak maradnak eredményeink.

\section{Összegzés}

A térségfejlesztési programok együttes hatásvizsgálata azok komplexitása és többdimenziós jellege miatt jelentős kihívás elé állítja mind a döntéshozókat, mind az elemzőket. Az eddig alkalmazott, az EU által kidolgozott értékelési eljárások joggal tárgyai a kritikának, hiszen nélkülözik a szigorúan vett elméleti és módszertani megalapozottságot. Az elmúlt két évtizedben a szakpolitikai programok ökonometriai hatáselemzése jelentős fejlődésen ment keresztül, de a legújabb módszertani eredményeket csak elvétve alkalmazzák a szakpolitikák értékelésekor.

A térségfejlesztési programok együttes hatáselemzése előtt álló legnagyobb kihívás a megfelelő teljesítményindikátor megalkotása. A programok 
komplexitása miatt nem elég egy-egy fontosnak tartott mutatószám, pl. az egy före jutó regionális GDP vagy a regionális munkanélküliség figyelembevétele. Ezek ugyanis a lehetséges hatásoknak csak egy (gazdasági, társadalmi, környezeti) dimenzióját képesek megragadni. Következésképp szükséges egy komplex mutatószám megalkotása, amely tartalmazhatja a lehetséges hatások összes releváns dimenzióját. Hasonlóan fontos, hogy a hatásokat lehetőleg minél alacsonyabb területi szinten tudjuk azonosítani, hiszen a magasabb vagy makroszintü hatások elrejthetik a mikroszintű hatások dinamikáját. Ezen a ponton viszont szembe kell nézni az empirikus vizsgálatok örök problémájával, a rendelkezésre álló adatok kérdésével. Bizonyos outputadatok, például a GDP csak NUTS3 szinten hozzáférhetők. Egy komplex térségfejlettségi indexnek a lehető legtöbb releváns információt, illetve az ezeket hordozó változókat kell magukba foglalniuk, ugyanakkor az adatok hozzáférhetősége nyilvánvalóan csak a változók önkényes szelekcióján alapulhat. Minden esetlegesség ellenére egy komplex mutatószám valós alternatívája a hivatalos indikátoroknak, amelyek a hatásoknak csak korlátozott körét képesek azonosítani.

Tanulmányunk két módon is hozzájárul a jelenlegi, fejlesztéssel foglalkozó irodalomhoz. Egyrészt Magyarországon először komplex térségfejlettségi index alkalmazásával azonosítottuk a térségek fejlettségi állapotát 2002 és 2008 között. Másrészt, szintén úttörő módon, a legújabb módszertani eredmények felhasználásával megpróbáltuk a rendelkezésünkre álló adatok alapján néhány fejlesztési program együttes hatását megbecsülni. Vizsgálatunk legfontosabb eredményei a következők.

A fejlesztési támogatások nagysága az EU-csatlakozást követően nagyságrendekkel növekedett. Ez együtt járt az egy projektre jutó támogatási összeg jelentős emelkedésével és a támogatások növekvő koncentrációjával az egyes kistérségek között. A legtöbb és a legkevesebb támogatást kapó kistérségek támogatási összege között nagyságrendbeli különbségek voltak. Budapest, a megyeszékhelyek és néhány város kiemelt módon részesült a fejlesztési támogatásokból. Érdekes módon ezzel együtt a támogatások szintjének konvergenciája is megfigyelhető. Ugyanakkor a támogatások eloszlásában jelentős mobilitás tapasztalható az egyes kistérségek között.

A fejlesztési támogatások hatását több módszerrel is megvizsgáltuk. Eredményeink arra utalnak, hogy általában elég nehéz bármilyen hatást is azonosítani, mivel azok érzékenyek a választott támogatási indikátorra. A kimutatott hatások nagysága nagyon kicsi, és negatív vagy pozitív irányú hatást is regisztráltunk. Számításaink eredményét csak kellő óvatossággal lehet értelmezni a korábban említett korlátok miatt. Ugyanakkor figyelembe véve a becsült hatások nagyságát valószínűleg nem tévedünk nagyot, ha azt állítjuk, hogy a fejlesztési programok nem gyakoroltak kimutatható hatást a kistérségek jóllétére. Kutatásunk csak az első lépés ahhoz, hogy jobban megértsük a térségfejlesztési programok együttes hatásmechanizmusait. 


\section{Irodalom}

Abadie, A., Drukker, D. Herr, J. L., Imbens, G. W. (2004): Implementing matching estimators for average treatment effects in Stata. Stata Journal, 3., 290-311.

Baker, J. H. (2000): Evaluating the impact of development projects on poverty. A handbook for practitioners. World Bank, Washington D. C. http://doi.org/c5wkg6

Bakucs L. Z., Fertő I. (2013): A vidékfejlesztési programok hatáselemzésének problémái a nemzetközi tapasztalatok tükrében. Erdélyi Múzeum, 3., 70-82.

Baltagi, B. H. (2008): Econometric analysis of panel data. 4th edition. Wiley, New York

Bernard, A. B., Durlauf, S. N., (1996): Interpreting tests of the convergence hypothesis. Journal of Econometrics, 1-2., 161-174. http://doi.org/bxtx5v

Caliendo, M., Kopeinig, S. (2005): Some practical guidance for the implementation of propensity score matching. DIW Berlin, IZA Bonn (Discussion Paper; 485.)

European Commission (2006): Rural development 2007-2013: Handbook on common monitoring and evaluation framework. Draft guidance document. Directorate General for Agriculture and Rural Development, EC, Brussels

Fertő I. (2006): Az agrárkereskedelem átalakulása Magyarországon és a kelet-közép-európai országokban. MTA KTI, Budapest (KTI Könyvek; 8.)

Fertő I., Varga Á. (2014): A jóllét területi különbségei Magyarországon: egy lehetséges térségfejlettségi index alkalmazása. Statisztikai Szemle, 10, 1-18.

Gertler, P. J., Martinez, S., Premand, P., Rawlings, L. B., Vermeersch, C. M. J. (2011): Impact evaluation in practice. World Bank, Washington D. C. http://doi.org/bjf585

Guo, S., Fraser, M. W. (2010): Propensity score analysis. Statistical methods and applications. Sage, London

Khandker, S. L., Koolwal, G. B., Samad, H. A. (2010): Handbook of impact evaluation. Quantitative methods and practices. World Bank, Washington D. C.

Kézdi G. (2010): A programok hatásvizsgálatának módszertana. In: Fazekas K., Kézdi G. (szerk.): Munkaerőpiaci tükör 2011. MTA Közgazdaságtudományi Intézet, Országos Foglalkoztatási Közalapítvány, Budapest, 54-71.

Leuven, E., Sianesi, B. (2009): PSMATCH2: Stata module to perform full Mahalanobis and propensity score matching, common support graphing, and covariate imbalance testing, Statistical software components, Boston College Department of Economics, http://econpapers.repec.org/RePEc:boc:bocode:s432001 (Letöltés: 2015. január 31.)

Lopez, C., Papell, D. H. (2012): Convergence of euro area inflation rates. Journal of International Money and Finance, 6., 1440-1458. http://doi.org/z7c

Michalek, J. (2012): Counterfactual impact evaluation of EU rural development programmes - Propensity score matching methodology applied to selected EU member states. Volume 2: A regional approach. JRC Scientific and Policy Reports, 1-79.

Michalek J., Zarnekow, N. (2012): Application of rural development index to analysis of rural regions in Poland and Slovakia. Social Indicators Research, 105, 1-37. http://doi.org/bpxzhs

Molnár A., Hamza E., Székely E., Varga E. (2010): Az EU társfinanszírozásával megvalósuló föbb vidékfejlesztési intézkedések átfogó értékelése. Agrárgazdasági Kutató Intézet, Budapest (Agrárgazdasági Tanulmányok; 2010/13.)

Németh N. (é. n.): A KSH T-STAR adatbázisa. MTA KRTK Adatbank, http://adatbank.mtakti.hu/files/ dokum/9.pdf.

Rosenbaum, P. R. (2002): Observational studies. 2nd edition. Springer, New York http://doi.org/z7d 